\title{
Exemplifying a Model-Eliciting Task for Primary School Pupils
}

\author{
Chan Chun Ming Eric \\ eric.chan@nie.edu.sg \\ Wanty Widjaja \\ wanty.widjaja@nie.edu.sg \\ Ng Kit Ee Dawn \\ dawn.ng@nie.edu.sg \\ National Institute of Education, Nanyang Technological University, Singapore
}

\begin{abstract}
Mathematical modelling is a field that is gaining prominence recently in mathematics education research and has generated interests in schools as well. In Singapore, modelling and applications are included as process components in revised 2007 curriculum document (MOE, 2007) as keeping to reform efforts. In Indonesia, efforts to place stronger emphasis on connecting school mathematics with real-world contexts and applications have started in Indonesian primary schools with the Pendidikan Realistik Matematik Indonesia (PMRI) movement a decade ago (Sembiring, Hoogland, Dolk, 2010). Amidst others, modelling activities are gradually introduced in Singapore and Indonesian schools to demonstrate the relevance of school mathematics with real-world problems. However, in order for it to find a place in the mathematics classroom, there is a need for teacher-practitioners to know what mathematical modelling and what a modelling task is. This paper sets out to exemplify a model-eliciting task that has been designed and used in both a Singapore and Indonesian mathematics classroom. Mathematical modelling, the features of a model-eliciting task, and its potential and advice on implementation are discussed.
\end{abstract}

Key words: Mathematical Modelling, Singapore, Indonesia, Model-Eliciting Task, Primary

Mathematics. Task Scaffolding

\section{Introduction}

Research have found that modelling activities help children in the promotion of important mathematical reasoning processes such as constructing, explaining, justifying, predicting, conjecturing, and representing (Chan, 2008; English \& Watters, 2005; Lehrer \& Schauble, 2000); reasoning aspects that are valued as a powerful way to accomplishing learning with understanding. Furthermore, studies have shown that children have been able to manage complex mathematical constructs irrespective of their academic mathematics achievement (Lesh \& Doerr, 2003). What is it about mathematical modelling that is asserted to be a promising reform effort in the mathematics classroom? This paper introduces mathematical modelling from a Models-and-Modelling Perspective (MMP) and shares the features of a modelling task (both from a Singapore and Indonesian context) towards understanding the potential of using such tasks. It will also discuss the potentials of the task and suggest teacher scaffolding strategies for task implementation.

\section{Mathematical Modelling}

There are various conceptions as to what mathematical modelling is just as there are various diagrammatic representations of the modelling process found in 
literature (e.g., Galbraith, Goos, Renshaw, \& Geiger, 2003; Lesh \& Zawojewski, 2007; Stillman, 1998). The common stance though is that mathematical modelling begins with a real-world problem or situation and the engagement process results in the representation of such problems in mathematical terms towards finding solutions to the problems. In this paper, we adopt a Models-and-Modelling Perspective (Lesh \& Doerr, 2003) where the modelling task used is termed as a Model-Eliciting Task. Based on the MMP, students develop internal conceptual models that are powerful but are under-utilized unless they are expressed externally through some representational media as they complete the modelling task. The external projection of the models can be expressed spoken language, written symbols, graphs, diagrams, and experiencebased metaphors. These representations are continually tested and revised as students aim to reach workable solutions. In this sense, the MMP focuses on students' representational fluency through the flexible use of mathematical ideas when students make mathematics descriptions of the problem context and data (Doerr \& English, 2003; Lesh \& Doerr, 2003).

The development of models takes place during the modelling process and is seen as involving mathematizing reality as contrasted with realizing mathematics (Lesh \& Doerr, 2003). The mathematical modelling process involves several stages. Figure 1 shows a generic 4-stage process. The stages include (a) understanding and simplifying the problem, (b) manipulating the problem and developing a mathematical model, (c) interpreting the problem solution, and (d) verifying and validating the problem solution.

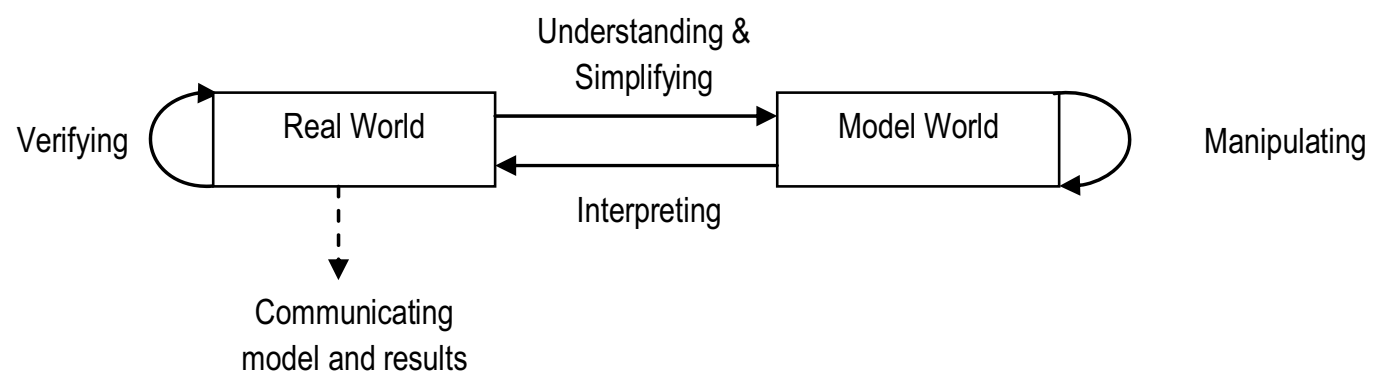

Figure 1. Modelling stages

\section{Features of a Model-Eliciting Task}

The mathematical modelling endeavour (involving a model-eliciting task) is commonly termed as a model-eliciting activity. During the modelling process, rich mathematical discourse and reasoning are made manifest during when students develop models. This is facilitated by the task when students confront it. As such, the 
design of the modelling task needs to ensure that the mathematics embedded can be surfaced when students are deeply engaged in it. Lesh, Cramer, Doerr, Post, and Zawojewski (2003) asserted a model-eliciting task is designed based on six instructional design principles: (1) the reality principle (i.e., elicits sense-making and extension of prior knowledge); (2) the model construction principle (i.e., warrants the need to develop a mathematically significant construct); (3) the self-evaluation principle (i.e., requires self- assessment); (4) the construct documentation principle (i.e., requires students to make visible their thinking); (5) the construct generalization principle (i.e., sharable, adaptable, reusable in other similar situations); and (6) the simplicity principle (i.e., the simplicities of the problem-solving situation). Thus the construct 'model-eliciting' circumscribes a problem-solving situation, its mathematical structure, the problem-solving processes and the mathematical models generated that are invoked by the problematic situation. The features of a modeleliciting task thus are what the principles aim to promote.

\section{An Example of a Model-Eliciting Task}

Figures 2 and 3 show the "Bus Route Task" for grade 5 (aged 10-11) students implemented in Singapore and Indonesian classrooms respectively between August to early November 2011. The two versions are deliberately designed to be parallel tasks so as to investigate the nature of student mathematical thinking and teacher pedagogical decision-making in the two educational systems. The two tasks share the same goal of determining the most efficient bus route for travelling from point $A$ to point B.

\section{Determining the most efficient bus route}

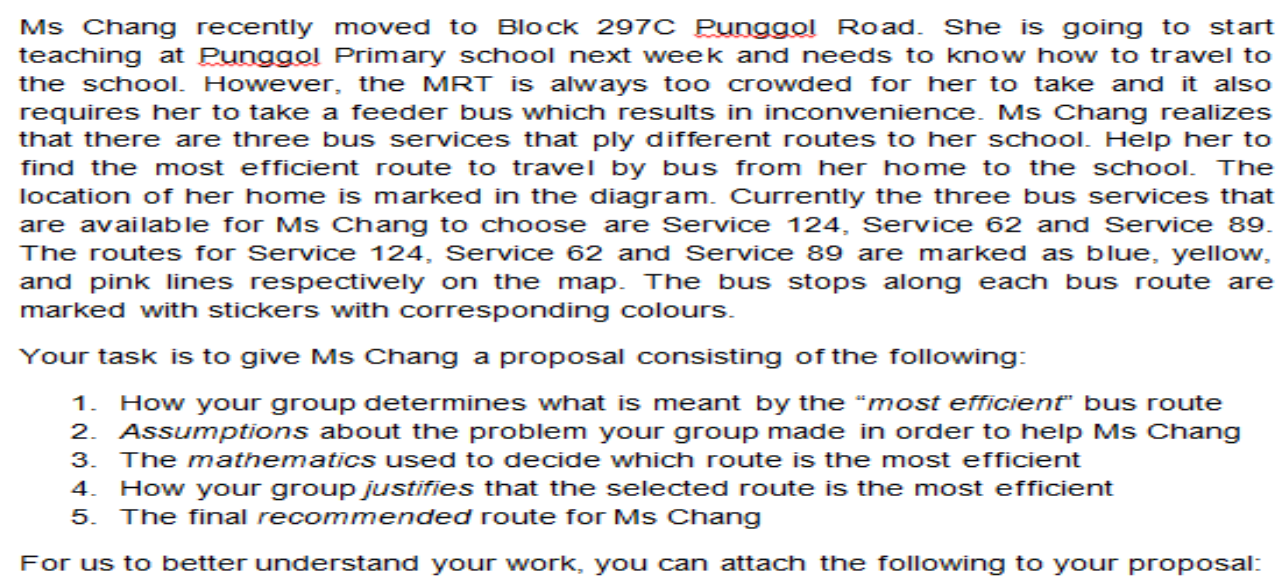




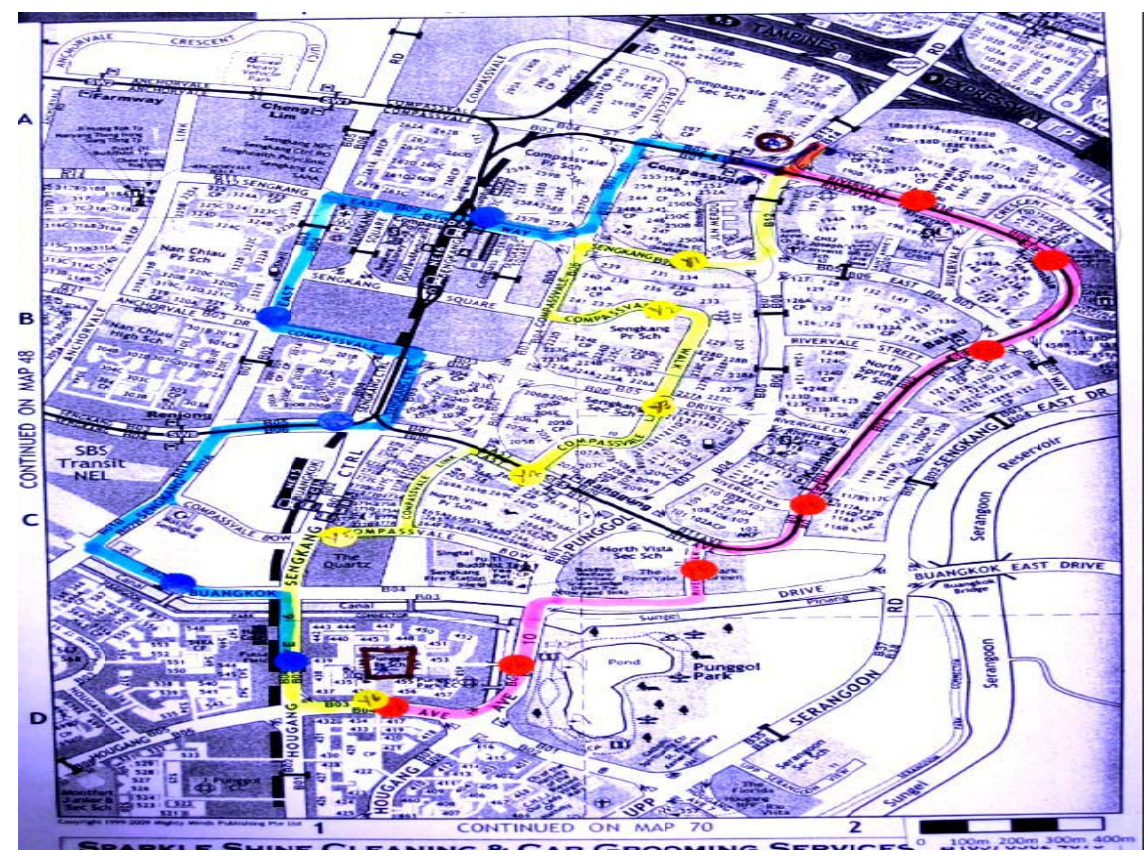

Figure 2. A sample of model-eliciting task (Singapore version)

\section{Menentukan jalur bus paling efisien}

Bu Mustari mendapat kunjungan tamu guru dari Singapore. Beliau ingin mengantar rombongan guru ini menggunakan bus dari terminal Jombor ke tempat kerajinan perak di Kota Gede. Ada 3 alternatif jalur bus yang dapat dipilih seperti tercantum pada peta. Ketiga alternatif jalur bus ditandai dengan warna biru, kuning dan merah muda pada peta. Pemberhentian bus di sepanjang jalur-jalur ini ditandai dengan stiker dengan warna yang sama dengan jalur bus.

Tugas kalian adalah membantu bu Mustari untuk memberi rekomendasi dengan menjawab pertanyaan berikut:

1. Bagaimana kelompok kalian menentukan jalur bus yang "paling efisien"?

2. Asumsi apa yang harus kalian buat untuk dapat membantu bu Mustari?

3. Bagaimana kalian menggunakan matematika untuk membantu Bu Mustari memilih jalur bus yang paling efisien?

4. Bagaimana kelompok kalian meyakinkan kelompok lain lewat penjelasan matematika bahwa jalur bus yang kalian pilih adalah yang paling efisien?

5. Rekomendasi akhir jalur bus yang paling efisien untuk bu Mustari.

Untuk membantu kelompok lain memahami penjelasan kelompok kalian, lampirkan dalam poster kalian:

(a) Peta yang memuat jalur bus yang kalian pilih

(b) Informasi penting yang kalian gunakan untuk menyelesaikan masalah 


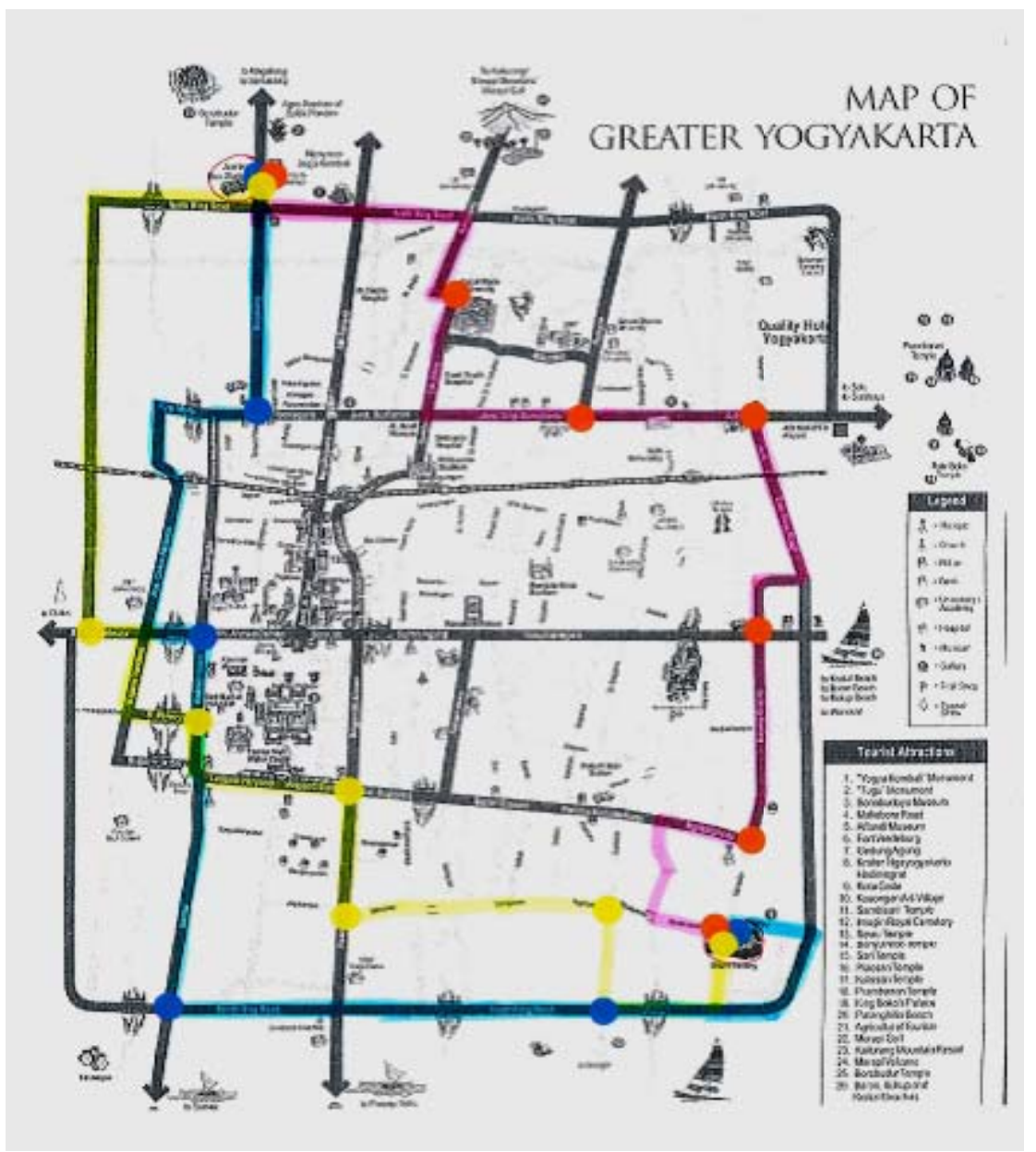

Figure 3. A sample of model eliciting task (Indonesian version)

\section{Potentials of the Task}

The tasks incorporated features of MMP and were presented to the students together with detailed maps of the respective areas mentioned in the task sheets. In particular, the information contained in these maps served as important data for use during the modelling process. For example, Figure 2 shows the map of Punggol area, as mentioned in the Singapore version of the Bus Route Task. Students participating in this task were to assist Ms Chang, a new teacher in their school, to select a most efficient bus route among three given colour-coded routes for travelling from Ms Chang's residence to the school. The starting point and ending point of travel were circled for ease of recognition. In addition, the positions of bus-stops along the three bus routes were marked by coloured stickers. The chosen map was deliberately a comprehensive one which also included information on the housing density along the routes, the scale measurement, and various land mark places within the area.

Through participation in the tasks, students engaged in the negotiation of meaning within the context of the task, interpret the problem situation and the data given in the map using their everyday experience, and use their chosen relevant 
mathematical concepts and skills to represent a solution to the problem in a coherent mathematical model. The tasks present platforms for students to organise their approaches based on their interpretations, explain and describe their mathematical reasoning, make conjectures and justify them, as well as compare among various options of mathematical models.

On the mathematical front, the two tasks carried rich potentials to bring forth relationships among pertinent variables such distance, time, and costs interpreted within real-world contexts. As the tasks were open-ended in nature, it allowed for a diversity of mathematical approaches. There were multiple pathways to derive at the mathematical solution depending on interpretations, assumptions and choice of variables, as postulated by proponents of the MMP perspective (e.g., English, 2010a; 2010b). Students' knowledge of pertinent mathematics (i.e., length, time, distance, average) and their flexibility of use for determining a valid mathematical model in presenting a solution to the problem would be important during mathematisation of the given real-world situation.

The modelling tasks were set as a group work for students to complete over three hours on three consecutive mathematics lessons. This offered a good platform for students to develop their mathematical communications skills during group and whole class discussion (English, 2010b). Students were required to justify their solutions and check the reasonableness of their solution. It was also ideal that students revisit their assumptions and the conditions set in the task in order to check if the solution needed further refinement. However, numerous studies on mathematical modelling have identified that validating results and re-interpreting the results in the real-world context proved to be challenging within the time constraints of classroom implementation (English, 2010a; Galbraith \& Stillman, 2006). The teachers involved in the implementation of the two tasks in the Singapore and Indonesian classrooms tried their best in helping their students refine the models within the constraints.

\section{Suggestions to Task Scaffolding}

This section will propose some teacher scaffolding suggestions for the implementation of the Bus Route Task which may apply across the Singapore and Indonesian classroom contexts. Firstly, it is important that the teacher sets aside time for students to discuss their interpretations of the context provided in the problem situation. For instance, students should be encouraged to brainstorm on what "efficient" means within the given context and how they would determine "efficiency" through use of mathematical measurements. At this stage, it is plausible that students would be able to suggest efficiency based on time, speed, and cost of travelling, well 
within their mathematical pre-requisites of the task. The scaffolding strategies of the teacher would be concentrating on questioning for ideas, exploration of possible choice of mathematical concepts and skills useful for the task, and helping students determine their next stage in the problem solving process. Students need to be reassured that multiple interpretations of "efficiency" are recognised and differing solution pathways for mathematical diversity are thus encouraged. They should also be allowed to put forth questions about task for clarifications.

Secondly, it is also important to help students understand the role of assumptions, conditions, and variables within the task. Assumptions are made about the context of the task (e.g., the bus travels at a constant speed, regular traffic conditions) so as to narrow down the focus for choice of appropriate mathematical approach. For example, it may be logical for students to assume regular traffic conditions (i.e., no vehicle break-downs, traffic lights are working) because data on traffic conditions vary day-to-day and it may not be readily available for the feasibility of classroom implementation. Conditions of the task need to be articulated and recorded because it would be necessary for students to decide on the parameters in which they would like to work within in order to develop a "mathematically valid" model as a proposed solution to the problem. For instance, one of the conditions in the Bus Route Task (Singapore version) where students can work with was to discuss the problem situation with the peak hour (i.e., 0630 - 07 30) of travelling stipulated, based on the starting time of their school. This helps in decision making about the frequency of bus services, along with other real-world considerations of day-to-day bus journeys. Variables of the tasks include the ways in which efficiency is measured (e.g., time, speed, cost). Students can be prompted to explore how these could be determined from the given information (i.e., map) and whether more information needs to be collected for more accurate calculations. Furthermore, these variables are also related to each other. Students can work on how to develop a more sophisticated mathematical model holistically connecting the variables to help determine the most efficient route from the given three routes.

Last and not least, model refinement requires continue evaluation of the mathematisation process and critique of initial models based on the validity and applicability to the given situation. It is crucial for students to be encouraged to reflect and review their initial models in several ways. For one, the appropriateness of assumptions made, conditions set, variables chosen for exploration. These form the foundation of the mathematical model or representation of the students' arguments and reasoning for their choice of the most efficient bus route. Students have to decide if the final decision made is a logical one, based on the above. Another way where students could review their initial model is to check their mathematical calculations 
for accuracy and reasonableness, whether these calculations present substantial support for their decision. Finally, students can reflect on their models to determine if it meets the requirements of the task. They need to recognise the possible limitations of their models for applications across other similar contexts (e.g., the most efficient train route) based on the parameters they had initially chosen to work with.

\section{Conclusion}

This paper serves three purposes to: (a) introduce the Model-Modelling Perspective (MMP) in mathematical modelling from a practice-oriented point of view; (b) exemplify a model-eliciting task (The Bus Route Task); and (c) discuss the potentials of the task and teacher scaffolding strategies. However, the implementation of modelling activities in classrooms can be challenging $(\mathrm{Ng}, 2011)$. Teachers who are used to prescriptive teaching approaches would need to explore other scaffolding approaches to more student-centred focus, encouraging multiple interpretations and solution pathways. Teacher beliefs about mathematics and how mathematics should be taught and applied may be challenged as mathematical models can take many forms; tables, graphs, and drawings, amidst abstract algebraic representations and calculations. In view of bridging the gap between the potentials of mathematical modelling and the recognition of these potentials by teachers, $\mathrm{Ng}$ (2011) recommends building teacher repertoire in two specific areas such as teacher questioning techniques during scaffolding and facilitating a conducive modelling climate in the classroom. The former recommendation has been elaborated in detail above based on the Bus Route Task. The latter recommendation is just as crucial for both teachers and students engaged in mathematical modelling as a positive climate which encourages inquiry, discussion, and fruitful mathematical arguments enhances sophisticated mathematical thinking.

\section{Acknowledgements}

The authors would like to thank the teachers (Mdm. Thomas Mary Magdalene \& Mdm. Mustari Admini) and schools (Punggol Primary School and SD Bopkri 3 Demangan Baru Yogyakarta) involved in the implementation of the Bus Route Task in Singapore and Indonesia. In addition, we are also grateful to Mrs Cynthia Seto, Master Teacher, Singapore, Ministry of Education, for her assistance in the research study based on the Bus Route Task. 


\section{References}

Chan, C. M. E. (2008). Mathematical modeling experiences for mathematical development in children. Thinking Classroom, 9(2), 37-45.

Doerr, H. M., \& English, L. D. (2003). A modelling perspective on students' mathematical reasoning about data. Journal for Research in Mathematics Education, 34, 110-136.

English, L. D., \& Watters, J. J. (2005). Mathematical modelling in third-grade classrooms. Mathematics Education Research Journal, 16(3), 59-80.

English, L. (2010a). Modeling with complex data in the primary school. In R. Lesh, P. L. Galbraith, C. R. Haines \& A. Hurford (Eds.), Modeling students' mathematical modeling competencies (pp. 287-299). New York: Springer.

English, L. (2010b). Mathematical modelling in the primary school. In I. Putt, R. Faragher \& M. McLean (Eds.), Mathematics education for the third millennium: Towards 2010 (pp. 207-214): MERGA.

Galbraith, P., Goos, M., Renshaw, P., \& Geiger, V. (2003). Technology enriched classrooms: Some implications for teaching applications and modelling. In QiXiao Ye, W. Blum, K. Houston, \& Qi-Yuan, Jiang (Eds.), Mathematical modelling in education and culture: ICTMA 10 (pp. 111-125). Chichester, UK: Horwood.

Galbraith, P. L., \& Stillman, G. (2006). A framework for identifying student blockages during transitions in the modelling process. ZDM, 38(2), 143-162.

Lehrer, R., \& Schauble, L. (2000). Inventing data structures for representational purposes: Elementary grade students' classification models. Mathematical Thinking and Learning, 21(1\&2), 49-72.

Lesh, R., Cramer, K., Doerr, H. M., Post, T., \& Zawojewski, J. (2003) Model development sequences. In R. Lesh \& H. Doerr, (Eds.), Beyond constructivism: Models and modeling perspectives on mathematics problem solving, learning and teaching (pp. 35-58). Mahwah, NJ: Lawrence Erlbaum Associates.

Lesh, R., \& Doerr, H. M. (2003). Foundations of a models and modeling perspective in mathematics teaching and learning. In R.A. Lesh \& H. M. Doerr (Eds.), Beyond constructivism: Models and modeling perspectives on mathematics problem solving, learning and teaching (pp. 3-34). Mahwah, NJ: Lawrence Erlbaum Associates.

Lesh, R., \& Zawojewski, J. (2007). Problem solving and modeling. In F. K. Lester (Ed.), Second handbook of research on mathematics teaching and learning: A project of the National Council of Teachers of Mathematics (pp. 763-803). Charlotte, NC: Image Age Publishing.

MOE. (2007). Ministry of Education Mathematics Syllabus - Primary, Singapore: Curriculum Planning and Developmental Division.

Ng, K. E. D. (2011). Facilitation and scaffolding: Symposium on Teacher Professional Development on Mathematical Modelling - Initial perspectives from Singapore. Paper presented at the Connecting to practice - Teaching practice and the practice of applied mathematicians: The 15th International Conference on the 
Teaching of Mathematical Modelling and Applications, Australian Catholic University (St. Patrick), Melbourne, Australia.

Sembiring, R. K., Hoogland, K., \& Dolk, M. (2010). A decade of PMRI in Indonesia. Utrecht: APS International.

Stillman, G. A., \& Galbraith, P. L. (1998). Applying mathematics with real world connections: Metacognitive characteristics of secondary students. Educational Studies in Mathematics, 36, 157-196. 